\title{
Stepwise clockwise rotation of the Cenozoic stress field in the Western Carpathians as revealed by kinematic analysis of minor faults in the Manín Unit (western Slovakia)
}

\author{
Viera ŠIMONOVÁ ${ }^{1, *}$ and Dušan PLAŠIENKA ${ }^{2}$
}

1 Matej Bel University, Department of Geography and Geology, Faculty of Natural Sciences, Tajovského 40, 97401 Banská Bystrica, Slovakia

2 Comenius University in Bratislava, Department of Geology and Palaeontology, Faculty of Natural Sciences, Mlynská dolina, Ilkovičova 6, 84215 Bratislava, Slovakia

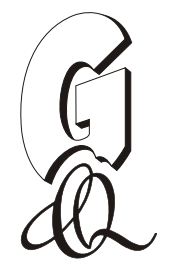

\begin{abstract}
Šimonová, V., Plašienka, D., 2017. Stepwise clockwise rotation of the Cenozoic stress field in the Western Carpathians as revealed by kinematic analysis of minor faults in the Manín Unit (western Slovakia). Geological Quarterly, 61 (1): 251-264, doi: $10.7306 / g q .1340$

This study aims at quantitative kinematic analysis of fault-slip data and palaeostress reconstruction of polyphase brittle structures developed in the Manín Unit cropping out in the Middle Váh River Valley of western Slovakia. The Manín Unit neighbours the Pieniny Klippen Belt that follows the boundary between the Paleogene accretionary wedge of the Outer Carpathians and the Cretaceous nappe system of the Central Western Carpathians. After the nappe emplacement during mid-Cretaceous times, the Manín Unit was incorporated into the Pieniny Klippen Belt and attained its complex tectonic style. Based on kinematic analysis of meso-scale faults with slickensides, six $\left(D_{1}-D_{6}\right)$ brittle deformation stages have been discerned. The relative succession of individual palaeostress states was derived from field structural relationships; their stratigraphic age was estimated primarily by comparison with other published data. Palaeostress analysis in the Manín Unit revealed the existence of six different palaeostress fields acting from the Middle Eocene to the Quaternary. The first three generations of meso-scale brittle structures were formed under a transpressional tectonic regime during the pre-Late Eocene-Early Miocene $D_{1}-D_{3}$ deformation. Generally, the maximum horizontal stress axis rotated clockwise from a W-E to an approximately $\mathrm{N}-\mathrm{S}$ direction. Thereafter, a transtensional tectonic regime was characterized by a WNW-ESE to NNW-SSE oriented minimum horizontal stress axis during Middle and Late Miocene $D_{4}-D_{5}$ deformation. A general extensional tectonic regime influenced the structural evolution of the area in the Pliocene to Quaternary, when a gradual reorientation of the palaeostress field resulted in the development of variable, often reactivated, fault structures.
\end{abstract}

Key words: faults, palaeostress reconstruction, tectonic regime, Manín Unit, Western Carpathians.

\section{INTRODUCTION}

The Manín Unit is located in the Púchov sector of the Pieniny Klippen Belt (PKB; Fig. 1), as its innermost element that covers a zone approximately $40 \mathrm{~km}$ long and 6-10 km wide. The Manín Unit spreads along the left side of the Middle Váh Valley from the district of llava up to the area west of town of Žilina. Mahel' (1967, 1980, 1985, 1986) affiliated the Manín Unit with the so-called Peri-Klippen Zone that can be defined as a group of units with Central Carpathian affinity incorporated in the PKB (see also Mello et al., 2011). Besides the Manín Unit, the Peri-Klippen Zone includes also the large Klape and Drietoma units. These units acquired "klippen style" structures (Manín and Butkov klippen, Klape klippe, Chotúč) after their nappe emplacement and during the deposition of the syn-orogenic, Gosau-type Upper

* Corresponding author, e-mail: viera.simonova@umb.sk

Received: December 14, 2015; accepted: November 24, 2016; first published online: January 13, 2017
Cretaceous to Eocene formations (Plašienka, 1995, 2012; Plašienka and Soták, 2015; Fig. 2).

The Manín Unit has been one of the most controversial units in the Western Carpathians. Even though many authors have studied its structure and composition, there is no generally accepted opinion about its tectonic classification and palaeogeographic position. During the past decades of research, three basic theories have emerged. The oldest one is Andrusov's concept $(1938,1968)$ of the Manín Unit as being an outer element of the Tatric (High Tatra) domain. This idea was primarily based on the occurrence of Urgon-type limestones in both the Manín and High Tatra successions and was further developed by Rakús et al. (1998) and Rakús and Hók (2005).

Another interpretation was proposed by Mahel' (1978), who advocated a palaeogeographic position of the Manín Unit to the south of the Tatric area and included it into the Fatric (Križna) nappe system, based on the similarity with the Belá subunit of the Križna nappe in the Strážovské vrchy Mountains. Many other authors such as Borza (1980), Michalík (1992, 1994), Reháková and Michalík (1994), Plašienka (1995, 2012) and Prokešová et al. (2012) followed Mahel"s interpretation and this view is accepted also in the present work (Fig. 2). 


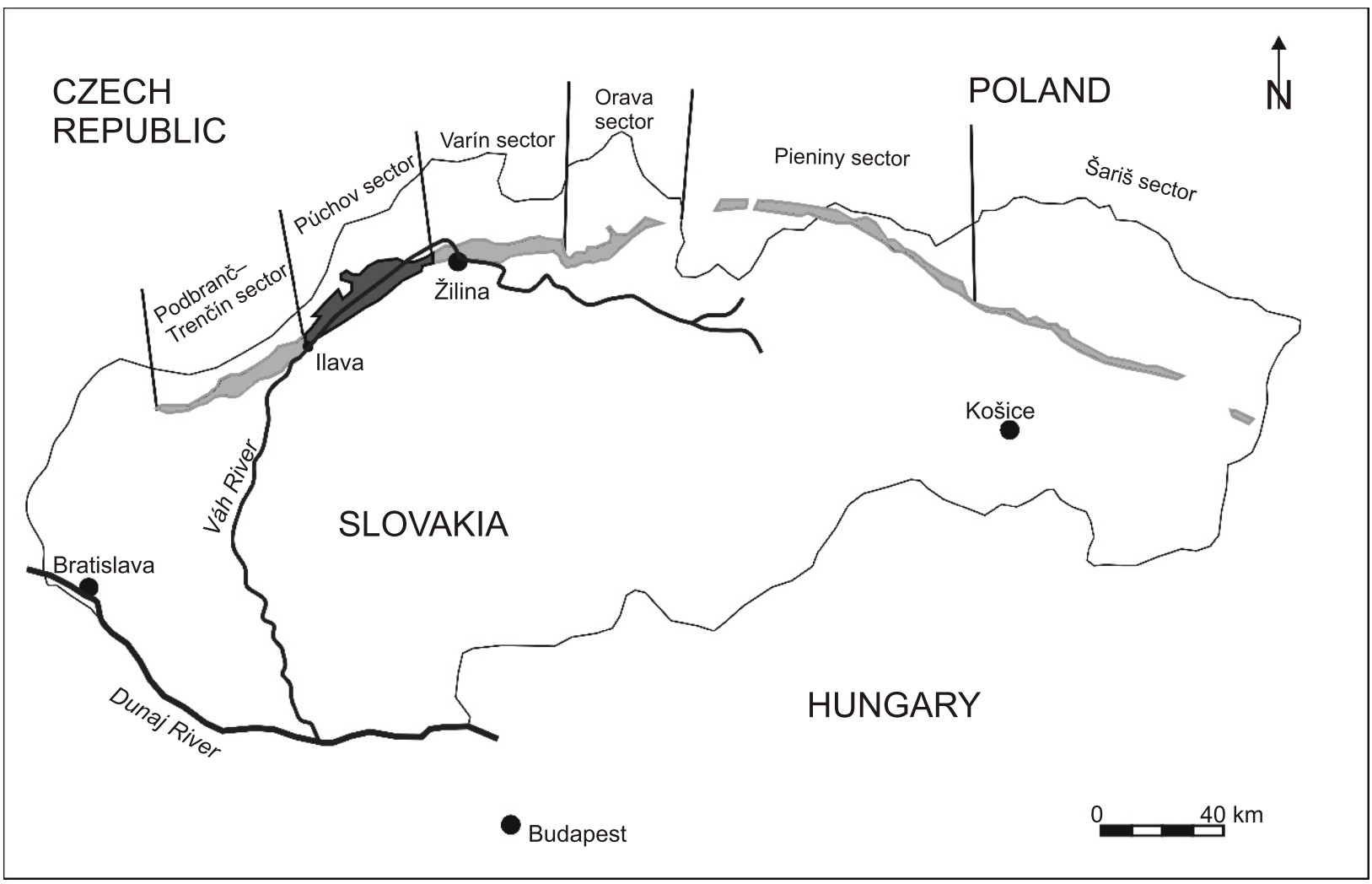

Fig. 1. Position of the area examined with respect to the Pieniny Klippen Belt (arcuate belt marked in grey)

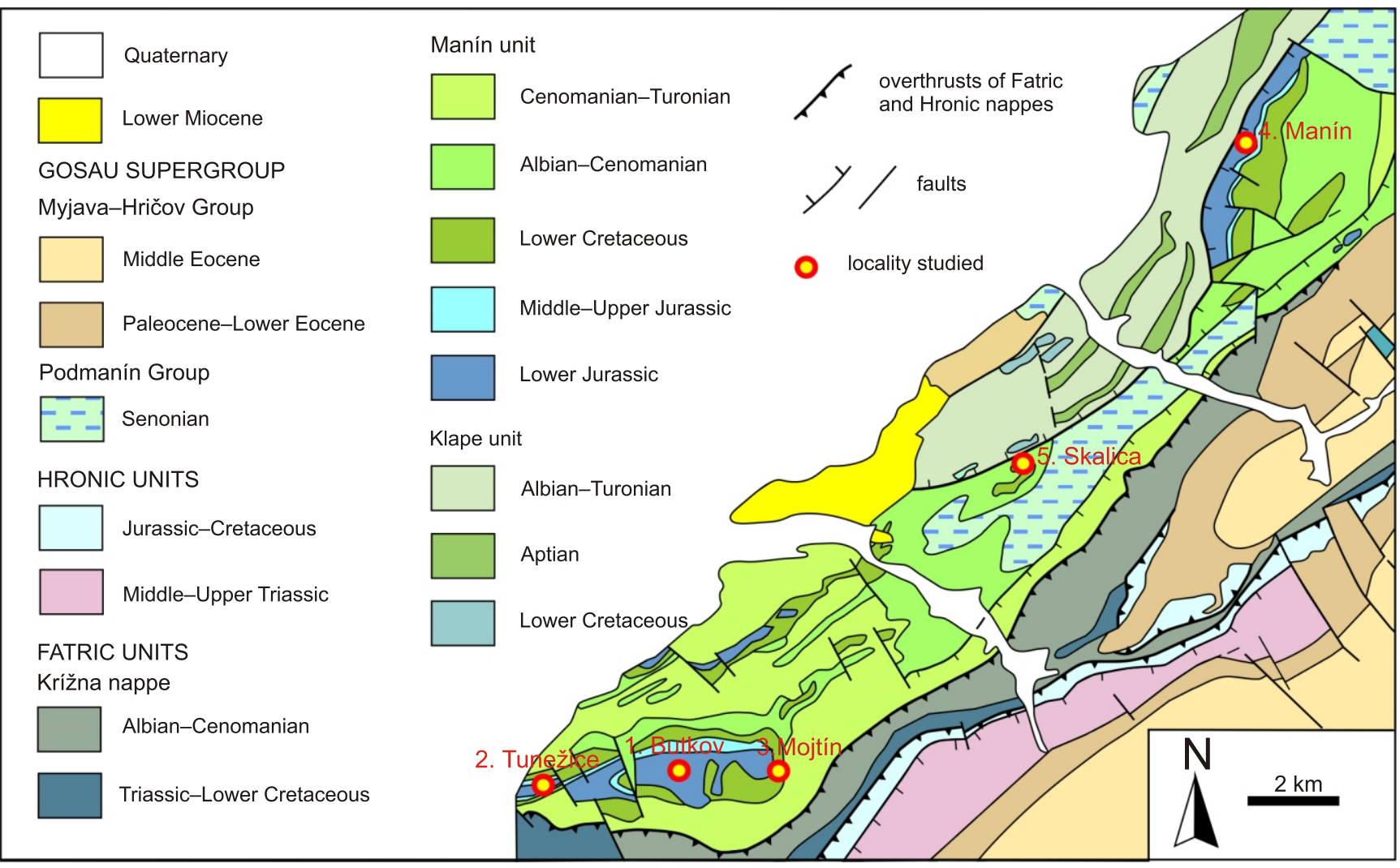

Fig. 2. Geological map of the study area (modified after Mello et al., 2005) with positions of the 5 localities studied (1-5) 
Still another concept was presented by Salaj and Samuel (1966), who presumed a continuous Early-Late Cretaceous sedimentary succession in the Manín Unit, whereas the Križna nappe and other Central Western Carpathian (CWC) units lack deposits younger than Turonian. By contrast, post-Turonian deposits are widespread in the PKB, but almost completely missing in the CWC. Consequently, the evolutionary trend of the Manín Unit corresponds rather to that of the PKB units; therefore, the Manín Unit was assigned to the Klippen Belt proper (Began, 1961, Began et al., 1963).

Notwithstanding its palaeogeographic setting, the Manín Unit became an element of the Western Carpathian accretionary wedge after its emplacement in front of the CWC stack of mid-Cretaceous basement-involved (Tatric, Veporic and Gemeric) and detached cover (Fatric, Hronic and Silicic) nappe systems (e.g., Froitzheim et al., 2008). As the wedge grew by frontal accretion of the PKB Oravic and Outer Carpathian Magura units, the Manín Unit was transferred to the rear part of the prograding wedge and was influenced by several folding-thrusting and extensional deformation stages (Plašienka and Soták, 2015). Based on the sedimentary record, these stages have been dated as Late Cretaceous ("Senonian") through Mid Eocene, followed by a widespread Bartonian-Priabonian transgression and an Oligocene collapse event affecting both the wedge and the adjacent part of the CWC to create the Central Carpathian Paleogene (a.k.a. Podhale) Basin (Soták et al., 2001; Plašienka and Soták, 2015 Kováč et al., 2016). Consequently, the Manín Unit was shaped by large-scale fold and thrust structures, such as the Butkov, Manín and Drieňovka "klippen" (actually doubly-plunging anticlines; cf. Plašienka et al., 2017), already before the Late Eocene. Here, we are dealing with brittle fault structures that virtually postdate the map-scale fold-thrust structures, i.e. they largely affect already tilted sedimentary strata of the Manín Unit.

The aim of this paper is the reconstruction of palaeostress fields in the Manín Unit, based on systematic fault-slip data collecting of mesoscopic faults at five main localities (Fig. 2). The data presented and their interpretation supplement results previously gathered in the large Butkov quarry (Šimonová and Plašienka, 2011) and extend structural observations to four other important exposures of the Manín Unit in western Slovakia.

\section{GEOLOGICAL SETTING}

The Western Carpathians are the northernmost, W-E trending segment of the European Alpides. They extend from the eastern end of the Eastern Alps toward the north-east, and are divided by the PKB into the Paleogene accretionary wedge of the External and the Cretaceous nappe system of the CWC.

The PKB represents a narrow but long zone dominated by Late Cretaceous-Early Miocene wrench tectonics (e.g., Ratschbacher et al., 1993; Nemčok and Nemčok, 1994). This is an internally complicated structural belt stretching in a broad arc for hundreds of kilometres from the Alpine-Carpathian junction as far as western Ukraine (Fig. 1). In its traditional definition, the PKB is formed by more-or-less isolated blocks of "klippen" (resistant Middle Jurassic to Lower Cretaceous limestones) embedded in the "klippen mantle" (soft Lower Jurassic and Upper Cretaceous to Paleogene shales, marls and flysch deposits). Consequently, the PKB has frequently been characterized as a tectonic megabreccia, a mélange, and even as a huge chaotic sedimentary body - an olistostrome (Nemčok, 1980). Regardless of its length, the PKB preserves its tectonic integrity, indicated by the omnipresence of the typical (Oravic) units that do not occur in other Carpathian zones. Additionally, certain parts of the PKB include also "non-Oravic" units of CWC provenance that were incorporated into the PKB and attained their tectonic style after the nappe emplacement during the mid-Cretaceous (e.g., the Klape and Manín Units). In all probability, they all represent frontal nappe elements of the Fatric nappe system (e.g., Plašienka, 1995).

The five localities investigated are located in the Púchov sector of the PKB (Fig. 1) in NW Slovakia. Being exclusively composed of Jurassic-Cretaceous formations, the Manín Unit is characterized by dominantly shallow-water limestones of Lower Jurassic and Lower Cretaceous age, followed by the Albian-Turonian hemipelagic marls and flysch deposits, which are overstepped by various Senonian deposits (Fig. 2). A thick formation of Barremian-Aptian platform limestones of Urgon-type is the most characteristic member of the Manín Unit (Fig. 3A). The older members crop out mainly in two large brachyanticlinal "klippes" - the Manín and Butkov anticlines. The mid-Cretaceous flysch of the Manín Unit is overridden from the SE by the frontal Fatric elements - the Križna nappe with its typical basinal Zliechov Succession (Fig. 2).

Senonian deposits occurring within the Manín Unit were considered either to be its integral continuous sequences (Salaj, 1990), locally separated by a stratigraphic hiatus (Marschalko and Kysela, 1979), or to represent tectonic windows of the underlying Kysuca Unit (Podháj Succession Rakús and Hók, 2005; Mello et al., 2005, 2011). Recently, Plašienka and Soták (2015) interpreted these deposits as post-emplacement overstep deposits of Gosau-type. As such, the Gosau strata are not constituents of the Manín and Klape units, just as they are not parts of the Austroalpine cover nappe system in the Northern Calcareous Alps (Plašienka and Soták, 2015 and references therein). Nevertheless, the Senonian rocks in the Manín and Klape belts were later strongly deformed at the rear of the developing accretionary wedge of the Outer Carpathians. Consequently, they were largely incorporated into the resulting fold-thrust structures of this "Peri-Klippen Zone".

Due to large exposures, particularly in the Butkov and Manín areas, the Jurassic-Lower Cretaceous sedimentary successions of the Manín Unit have been described in a great detail in many papers (e.g., Rakús, 1977; Michalík and Vašíček, 1984; Borza et al., 1987; Vašíček et al., 1994; Rakús and Hók, 2005; Mello et al., 2011; Michalík et al., 2012, 2013). In general, the Butkov Succession is composed of Lower Jurassic syn-rift sandy-bioclastic limestones and then by Middle Jurassic-Lower Cretaceous, mostly basinal pelagic, well-bedded nodular, siliceous, marly and cherty limestone formations overlain by a thick layer of massive, biodetrital Urgon-type limestone (Barremian-Early Albian) followed by a drowning sequence of Albian hemipelagic marls and coarsening-upward synorogenic flysch deposits of mainly Cenomanian age.

The Butkov structure is a brachyantiform $5 \mathrm{~km}$ long and $1.5 \mathrm{~km}$ wide cored by relatively competent Jurassic to Lower Cretaceous strata surrounded by mid-Cretaceous marls and flysch deposits. The Butkov antiform is slightly asymmetrical, with a steeply $\mathrm{N}$-dipping to vertical northern limb and a moderately to steeply S-dipping southern limb, affected also by S-dipping low-angle normal faults (Borza et al., 1987; Michalík et al., 2012). The Butkov Succession is exposed in three large artificial exposures - the Butkov, Tunežice and Mojtín quarries located within the core of the Butkov antiform (Fig. 2).

The large, 15-level Butkov quarry is situated on the northern slopes of Mt. Butkov (765 m a.s.I.) in the central part of the brachyantiform. Limestones as a raw material for cement production are mined there. The Tunežice quarry is situated near Ladce village on the western slopes of Kalište Hill (679.5 m), which is located at the western axial closure of the Butkov struc- 

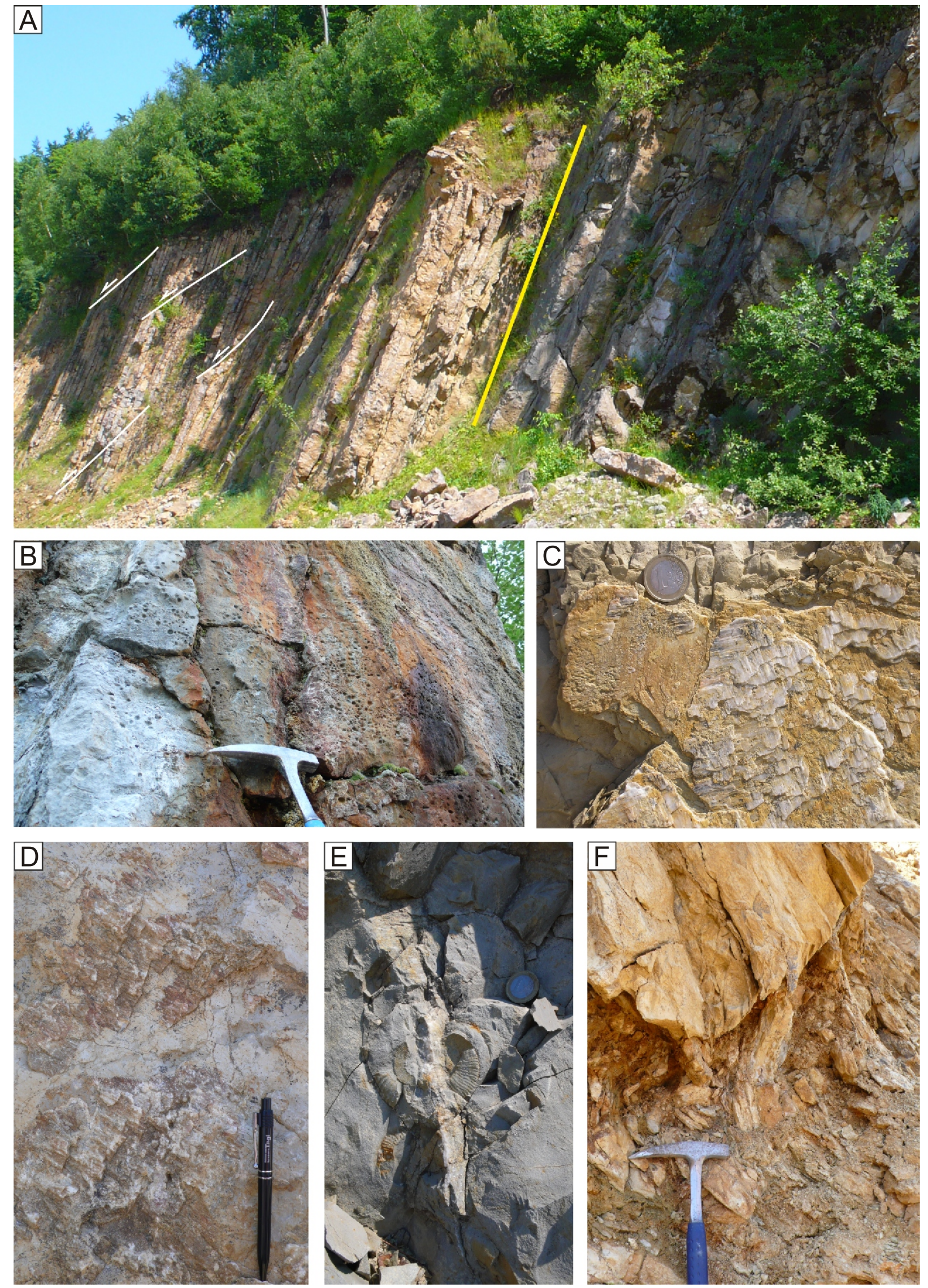

Fig. 3. Examples of brittle deformational structures observed in the field

A - view of the Butkov quarry (locality 1 ) - the yellow line represents the contact of two Lower Jurassic limestone formations; white lines - normal faults of the youngest deformation stage; B - massive Barremian to Lower Albian "Urgon" limestones covered by a hard-ground; $\mathbf{C}$ - example of the superposition of younger subvertical calcite slickenfibres with accretionary mineral steps on older subhorizontal fault striae on a single fault surface; $\mathbf{D}$ - typical calcite accretionary mineral steps on a fault plane; $\mathbf{E}-$ an ammonite bisected by a fault plane filled with fibrous calcite; $\mathbf{F}$ - shear zone with observed drag folds 
ture. An anticlinal macrofold structure of Lower Jurassic strata continuing from the Butkov quarry is clearly visible through several quarry stages. The Mojtín quarry is situated in the valley of the Slatinský potok brook near village Belušské Slatiny, close to the eastern periclinal closure of the Butkov anticline.

Compared to the Butkov Succession, the Manín Succession is somewhat different, of more shallow-water character with a prevalence of condensed swell facies and with a layer of massive Urgonian limestones up to 200 metres thick. The Manín Succession is exposed in a narrow gorge incised in the large Manín antiform (locality Manín) and in the smaller Drieňovka pericline. There are no quarries in this area, and so only natural exposures providing a limited number of measurable fault structures have been analyzed.

The Skalica zone occurring between the Butkov and Manín antiforms (Fig. 2) is strongly imbricated, whereby narrow slices of Lower Cretaceous strata often reflect a slope environment. The Skalica locality occurs near the town of Považská Bystrica $1 \mathrm{~km}$ SSE of Dolný Moštenec village. It exposes two small klippes formed by Lower Cretaceous limestones and, in particular, Upper Aptian mass-flow breccias composed of clasts of Urgonian limestone (e.g., Michalík and Vašíček, 1984).

\section{METHODS}

Being clearly superimposed on the Late Cretaceous-Early/Middle Eocene fold-and-thrust structures, the brittle fault structures investigated should represent a record of the post-Lutetian tectonic evolution of the study area. In our analysis, we have omitted the dip-slip slickenlines occurring on bedding planes on a limb of the Butkov pericline, which obviously formed by flexural slip during its growth; it was analysed in detail by Bučová (2013). However, the steepened limbs of the Manín anticlines - the vertical northern limb of the Butkov antiform in particular - were reactivated as strike- or oblique-slip faults.

Palaeostress reconstruction of post-folding fault structures in the Manín Unit was based on detailed field observations. Our approach included measurement of meso-scale structural data of fault-slickensides and their kinematic analysis, based on the evaluation of fault surfaces. The fault-slip data included the dip and direction of slickenlines occurring on fault planes, the sense of displacement of fault blocks and quality assessment of the displacement criteria. The sense of displacement can be determined using kinematic indicators on the slickenside surfaces. The main criteria used to identify the direction and sense of fault slip were summarized for instance by Petit (1987) and Angelier (1989, 1994), and include various structures such as grooves, slickenfibres and slickolites, striae, mineralised steps, Riede shears, offsets of markers, stepovers, drag folds etc. (Fig. 3) The quality ranking scheme according to the World Stress Map Project ranges from $A$ (best) to $E$ (worst) and is determined as a function of several criteria (Sperner et al., 2003). The basic principle of palaeostress analysis is that meso-scale structures can be related to larger regional structures; both scales should reflect the same dynamics and kinematics (Angelier, 1989, 1994).

A typical approach to the reconstruction of the palaeostress field is the inverse method, which is based on the assumption that the fault movement is generated in the direction of maximum shearing stress (Wallace, 1951; Bott, 1959). The inverse problem consists of determining the mean stress tensor, knowing the orientation and sense of slip on numerous faults. In practice, the best fit, representing a common stress tensor, between all fault-slip data that belong to a given tectonic event is numerically calculated (Angelier, 1994; Marko, 2000; Vojtko and Marko, 2006). The inverse method presumes that each planar surface, an existing or newly formed fault, may be activated in a given stress state.

Fault plane and slickenside orientations, including slip senses, are used to compute the four parameters of palaeostress tensor: the principal stress axis $\sigma_{1}$ (maximum compression), $\sigma_{2}$ (intermediate compression) and $\sigma_{3}$ (minimum compression) and the ratio of principal stress differences $R=\left(\sigma_{2}-\sigma_{3}\right) /\left(\sigma_{1}-\sigma_{3}\right)$. These four parameters are determined using an improved version of the Right Dihedron method of Angelier and Mechler (1977) and the new interactive rotary optimizing method SHEAR, using the software package WinTensor developed by Delvaux (2006).

The data used for inversion are measured fault plane and slip line orientations, whereas a sense of movement was derived from the geometry of calcite steps on slickensides (Fig. 3C, D). The WinTensor inversion method first determines the directions of principal stress axes by using the Right Dihedra method, a graphical method for determination of the range of possible $\sigma_{1}$ and $\sigma_{3}$ orientations (Angelier and Mechler, 1977). With this method, the nodal planes of any incompatible datum are eliminated. This initial result is used as a starting point for the rotational optimization. For faults, the angular deviation between observed slickensides and computed shears is minimized, together with the maximization of friction coefficients for each fault plane. The WinTensor procedure optimizes the results by progressive rotation of the tested tensor around each of its axes, and by testing different values of $R$. The range of rotation angles and values of $R$ ratio tested are progressively reduced, until the tensor is stabilized (Delvaux, 1993; Delvaux and Sperner, 2003). Separation of fault populations resulting from successive tectonic regimes is based on the interactive kinematic separation and progressive stress tensor optimization, to obtain homogeneous subsets, representing different stress regimes. Their chronological succession is established as a function of structural and geological criteria and by comparison to known regional tectonic events.

Stress regimes are defined based on the orientation of stress axes and the magnitude of the parameter $R$ ' with values ranging from 0 to 3 (Delvaux et al., 1995, 1997):

- normal faulting when $\sigma_{2}$ is the maximum horizontal compression axis ( $\sigma_{2}$ SHmax) and $\sigma_{1}$ is vertical; $R^{\prime}=R(0-1)$ - extensional regime;

- strike-slip faulting when $\sigma_{1}$ is the maximum horizontal compression axis ( $\sigma_{1}$ SHmax) and when $\sigma_{2}$ is vertical; $R^{\prime}=2-R(1-2)$ - strike-slip regime;

- thrust/reverse faulting when $\sigma_{1}$ is the maximum horizontal compression axis ( $\sigma_{1}$ SHmax) and $\sigma_{3}$ is vertical; $R^{\prime}=2+R(2-3)$ - compressional regime.

Critical considerations on the accuracy of stress inversion methods are given in Dupin et al. (1993), Pollard et al. (1993), Nieto-Samaniego and Alaniz-Alvarez (1996), Twiss and Unruh (1998), Maerten (2000) and Roberts and Ganas (2000). They concluded that uncertainties in the stress tensor determination due to geological and mechanical factors generally fall in the range of measurement errors. Because the regional stress tensor is spatially and chronologically homogeneous in the entire rock mass, stress computation utilizing the inversion method should be suitable. The calculation can be influenced by three effects: (1) the ratio between the width and length of a fault; (2) the effect of the Earth surface (topoeffect); (3) the interaction among faults (Pollard et al., 1993). Palaeostress analysis results can be compromised by all the above-mentioned effects; however, their influence is usually minimal (Angelier, 1994). 


\section{RESULTS}

The deformational history of the Manín Unit is characterized by a multistage ductile-brittle and brittle tectonic evolution that occurred in six $\left(D_{1}-D_{6}\right)$ deformation stages producing variably oriented populations of fault-slip structures (Fig. 3). Structural analysis of brittle deformation that affected the Jurassic and Lower Cretaceousţ rocks of the Manín Unit at five main localities (Butkov quarry - locality 1, Tunežice quarry - locality 2, Mojtín quarry - locality 3, Manín narrows - locality 4 and Skalica klippe - locality 5) was carried out based on the interpretation of palaeostress states. A robust dataset of more than 2,100 slickensides was used to determine the orientation of principal palaeostress axes $\left(\sigma_{1}, \sigma_{2}, \sigma_{3}\right)$ and to define the $R$ parameter (Appendix $1^{*}$ ). Selected representative stereograms of homogeneous fault populations are shown in Figures 4-9. Around 200 measurements were omitted because they are incompatible and show unreasonable results. This may be due to measurement errors in the field or structural inheritance. The six distinct palaeostress states caused by the six $\left(D_{1}-D_{6}\right)$ deformation stages were detected from $>80$ computed reduced stress tensors (Appendix 1).

The relative succession of individual palaeostress states was derived from field structural relationships and overprinting criteria. However, estimation of their possible age limits is more problematic. We have analysed only fault structures in Mesozoic rocks and there is no age control from Cenozoic strata in the area investigated. The Lower Eocene carbonate conglomerates, which rim the SE margin of the Manín zone (Fig. 2), do not provide enough data, since there are only natural expo- sures where most of faults do not provide reliable shear-sense criteria due to weathering. In such a situation, the tentative stratigraphic age estimates of individual palaeostress and separate deformation stages presented below are established by comparison and correlation with a wealth of well age-constrained palaeostress data and interpretations from the adjacent SW parts of the Western Carpathians (e.g., Marko et al., 1991, 1995; Kováč et al., 1994; Fodor, 1995; Hók et al., 1995; Kováč and Hók, 1996; Fodor et al., 1999; Vojtko et al., 2008, 2010; Pešková et al., 2009; Králiková et al., 2010). The results and chronology of faulting are presented herein from the oldest to the youngest deformation phases $\left(D_{1}\right.$ to $\left.D_{6}\right)$.

\section{FIRST $\left(D_{1}\right)$ DEFORMATION STAGE, W-E COMPRESSION (PRE-LATE EOCENE)}

The oldest brittle deformation phase observed is characterized by compression in the W-E direction that was generated during the strike-slip to dextral transpressional tectonic regime. Dextral, SW-NE oriented strike-slip faults dominate over conjugate sinistral strike-slip features (Fig. 4). The oblique-slip reverse faults striking in the N-S to NNE-SSW direction, generated in a pure compressive regime, are superimposed on older fault structures. The calculated reduced stress tensor is characterized by the $\mathrm{W}-\mathrm{E}$-oriented principal compressive stress axis $\left(\sigma_{1}\right)$ and $\mathrm{N}-\mathrm{S}$ oriented minimum principal stress axis $\left(\sigma_{3}\right)$, which fluctuates from a subhorizontal to a subvertical position, thereby the tectonic regime switched between pure strike-slip, transpressional and pure compressional, respectively. Brittle deformation structures of this stage are well-preserved at all lo-

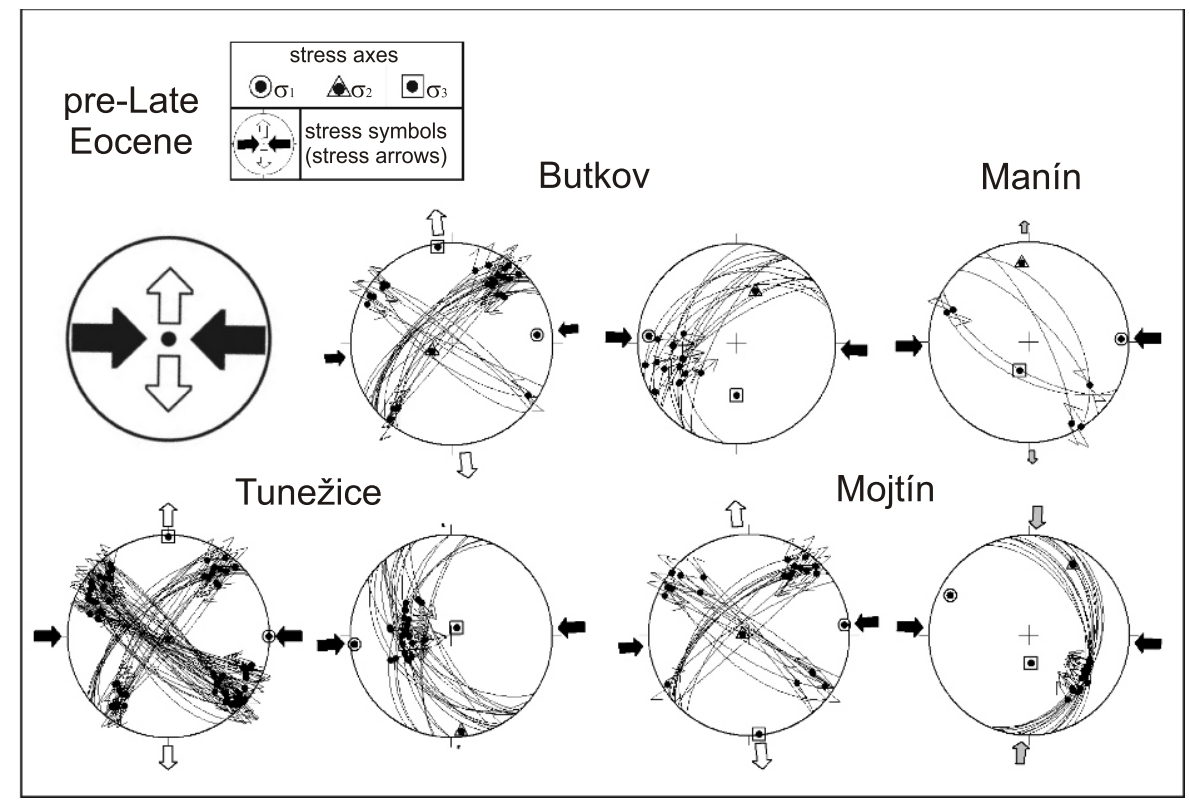

Fig. 4. Representative diagrams of fault-slip data orientation and their palaeostress interpretation for the first $D_{1}$, pre-Late Eocene deformation phase of $\mathrm{W}-\mathrm{E}$ compression

The stress circle denotes the mean maximum horizontal compression (SHmax) by black arrows and the least horizontal stress (Shmin) by empty arrows. The dimensions of arrows indicate their relative magnitudes. Each selected homogeneous group of faults is represented by a stereogram, in which the fault planes are plotted as great circles with observed slip lines (dots) and slip senses (arrows) using stereographic projection (Schmidt net; lower hemisphere). Symbols of the calculated principal stress axes: circles $-\sigma_{1}$, triangles $-\sigma_{2}$, squares $-\sigma_{3}$ 


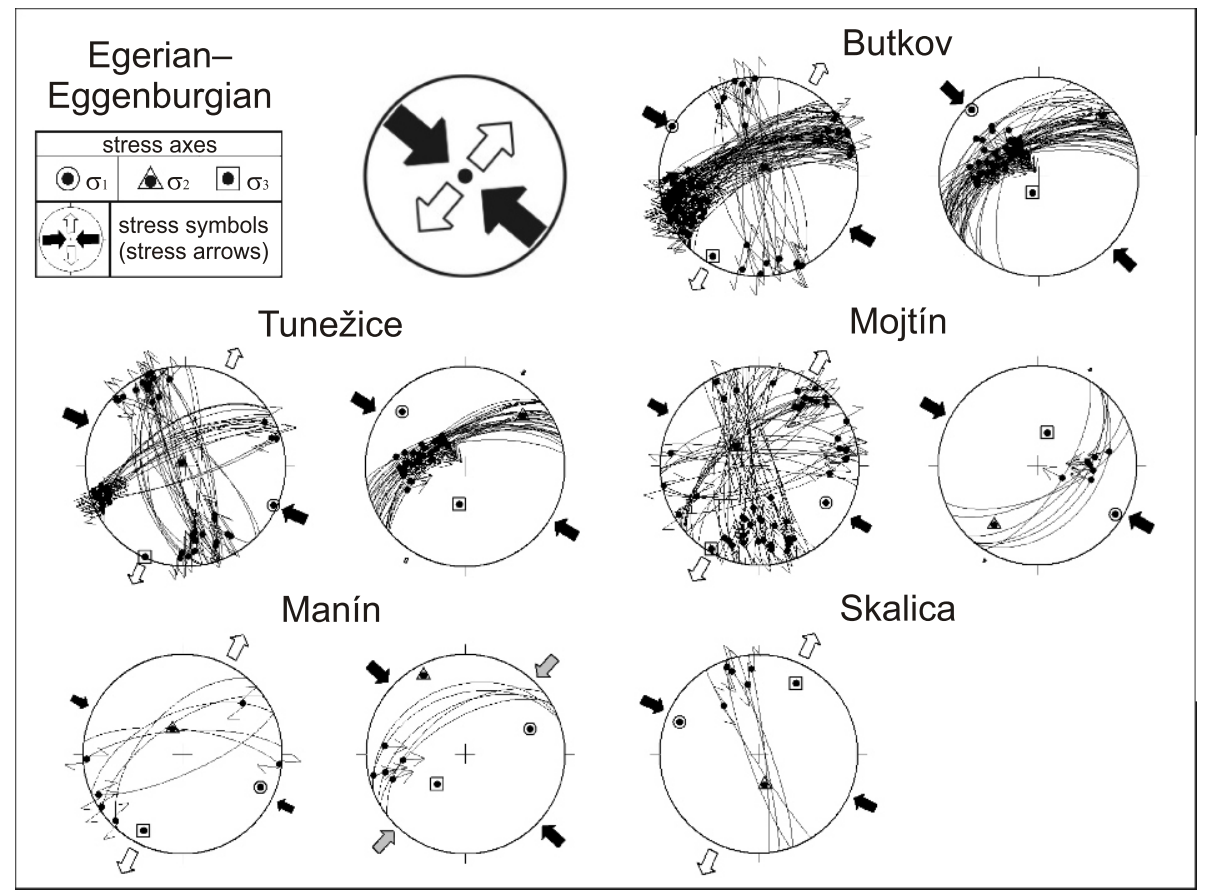

Fig. 5. Representative diagrams of fault orientation and their palaeostress interpretation for the second $\mathrm{D}_{2}$ deformation phase of WNW-ESE (NW-SE) compression (Egerian-Eggenburgian)

For explanations see Figure 4

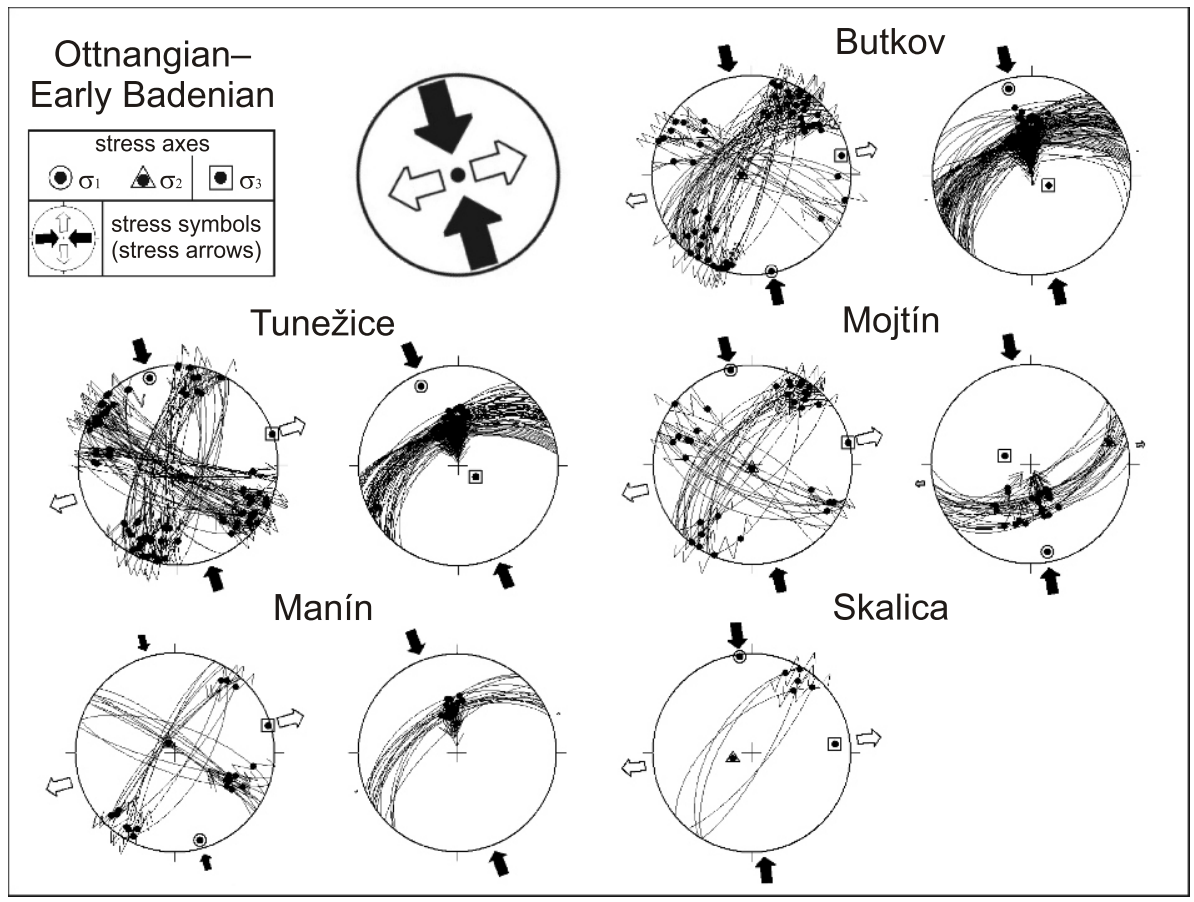

Fig. 6. Representative diagrams of fault orientation and their palaeostress interpretation for the third $\mathrm{D}_{3}$ deformation phase characterized by NNW-SSE (N-S) oriented main compression axis (Ottnangian-Early Badenian) 
Middle-

Late Badenian

\begin{tabular}{|c|c|c|}
\hline \multicolumn{3}{|c|}{ stress axes } \\
\hdashline$\sigma_{1}$ & $\Delta \sigma_{2}$ & $\bullet \sigma_{3}$ \\
\hline & $\begin{array}{l}\text { stress symbols } \\
\text { (stress arrows) }\end{array}$ \\
\hline & &
\end{tabular}
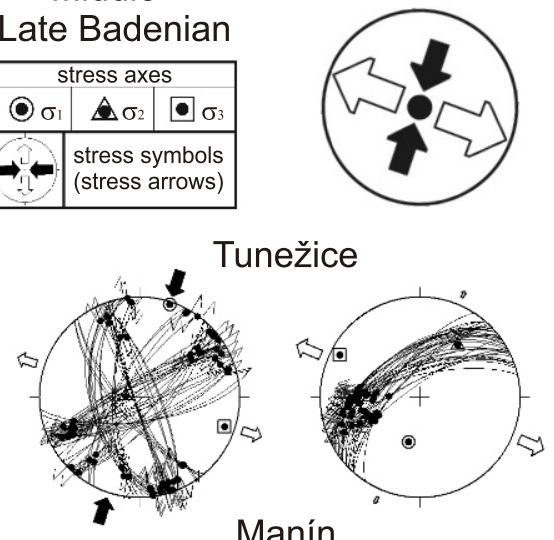

Manín
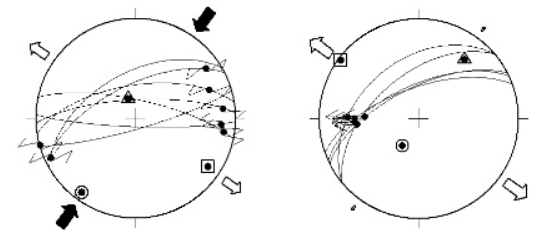

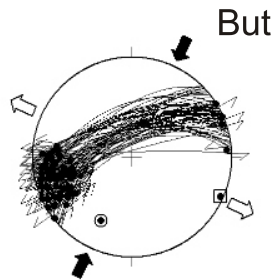

Butkov

Mojtín

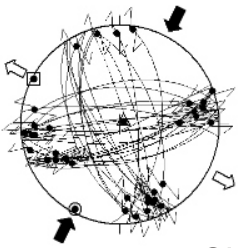

Skalica
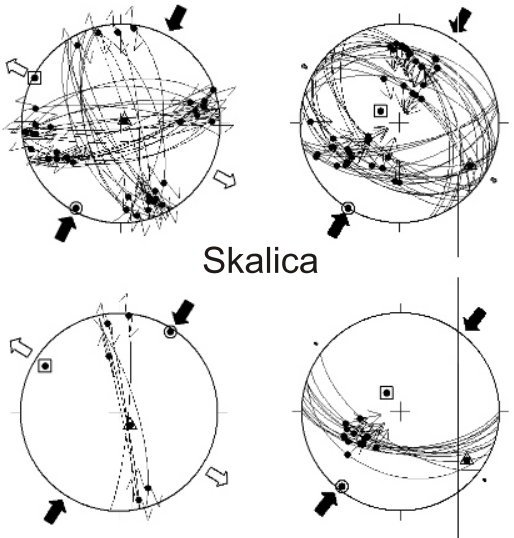

Fig. 7. Structural diagrams of fault orientation and their palaeostress interpretation characterizing the fourth $\mathrm{D}_{4}$ deformation phase with NNE-SSW compression and WNW-ESE extension (Mid-Late Badenian)

For explanations see Figure 4

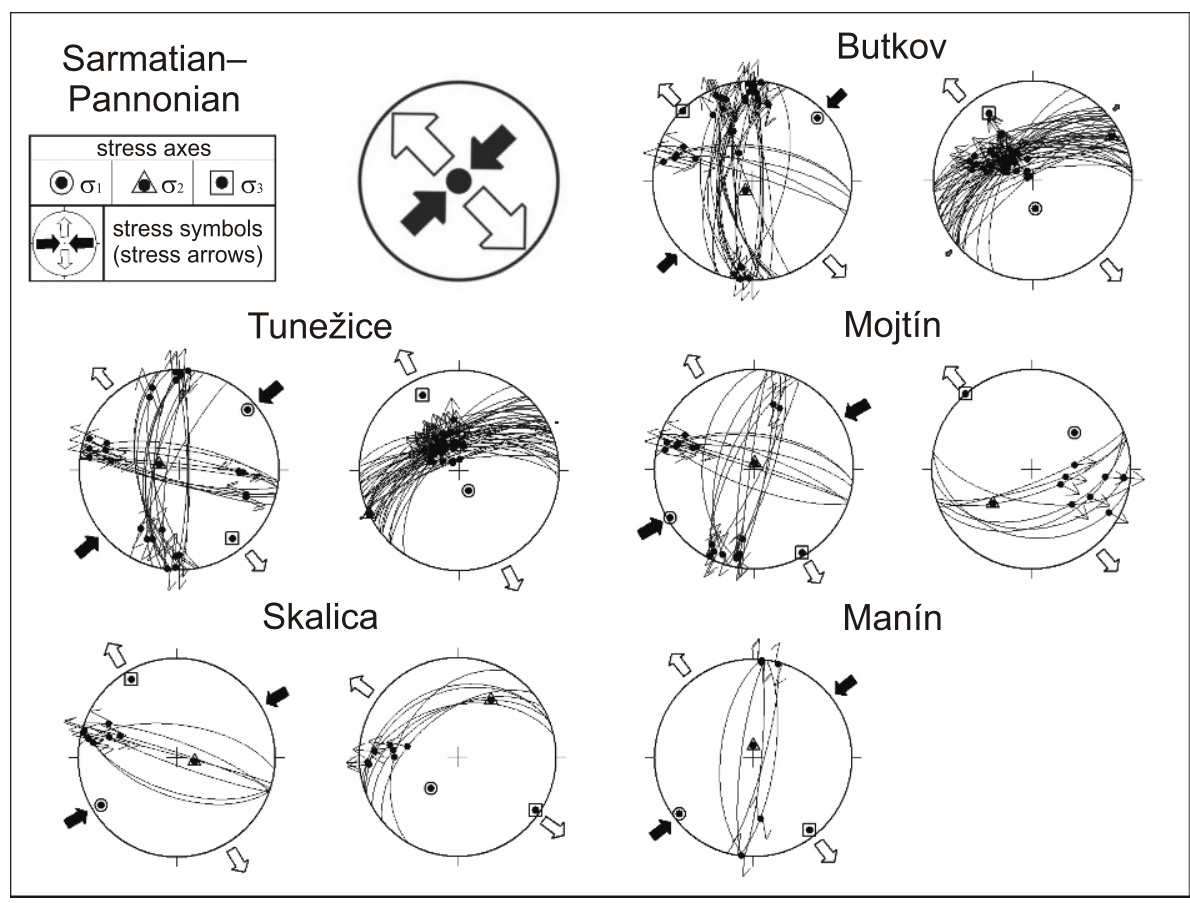

Fig. 8. Structural diagrams of fault orientation and their palaeostress interpretation indicating a sinistral transtensional tectonic regime during the $D_{5}$ deformation stage characterized by NW-SE extension and waning NE-SW compression

(Sarmatian-Panonian)

For explanations see Figure 4 


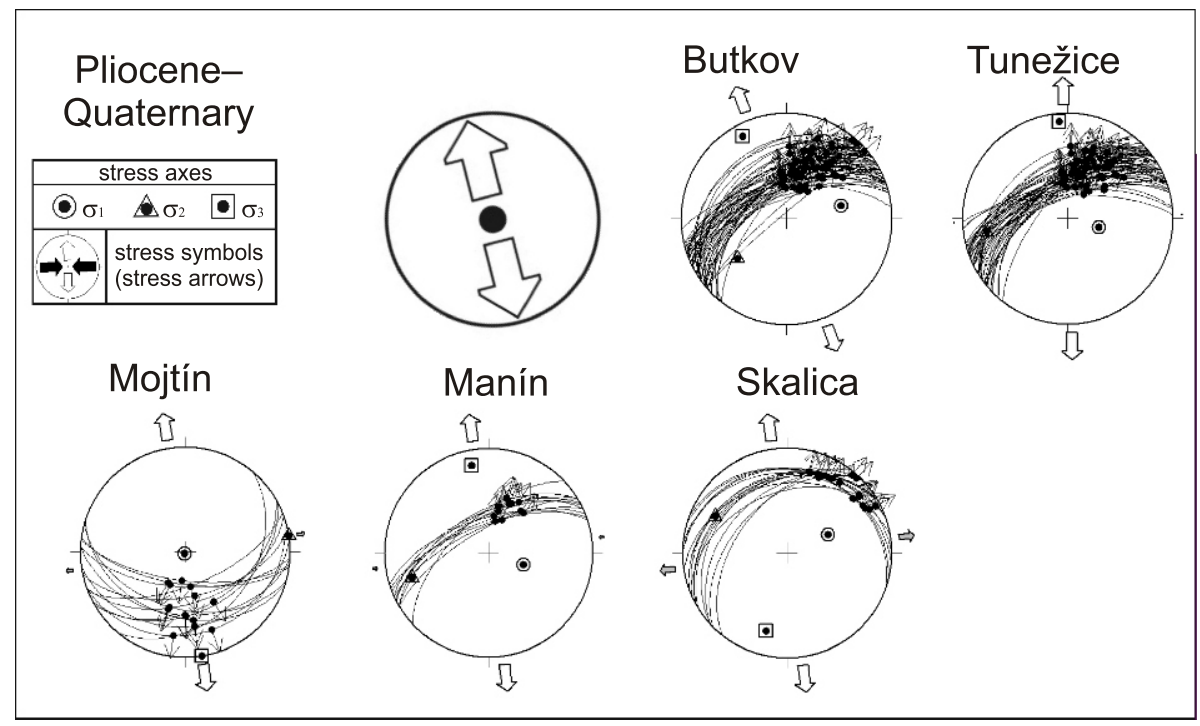

Fig. 9. Stereograms of faults indicating the general NW-SE extension during the last $D_{6}$ deformation stage (Pliocene-Quaternary)

For explanations see Figure 4

calities, except for the Skalica site (locality 5). In general, the first brittle deformation stage reconstructed was related to $\mathrm{W}-\mathrm{E}$ oriented contraction combined with a dextral transpressional regime that only affected rocks older than Upper Eocene in other Western Carpathian areas (e.g., Vojtko et al., 2010). Consequently, it should have taken place during the Early-Middle Eocene, or even earlier - back to Cretaceous/Paleocene boundary times (cf. Marko et al., 1995; Fodor et al., 1999).

\section{SECOND $\left(D_{2}\right)$ DEFORMATION STAGE, WNW-ESE TO NW-SE COMPRESSION (EGERIAN-EGGENBURGIAN)}

The second tectonic phase corresponds to a gradual change from a strike-slip tectonic regime, represented by strike-slip faults formed under the WNW-ESE directed principal compressive stress axis to a compression-dominated regime with NW-SE contraction, recorded by a great number of SW-NE striking oblique reverse faults. The strike-slip faults are mostly dextral features oriented SW-NE (Fig. 5), whilst the sinistral strike-slip faults trend NNW-SSE. At the Butkov locality (locality 1 ), many of the SW-NE to WSW-ENE trending, steeply NW-dipping dextral strike-slips reactivate the bedding planes of similar orientation. Based on regional considerations, this complex fault system controlled by the WNW-ESE to NW-SE oriented main compressive stress axis was likely formed during the Late Oligocene to earliest Miocene (Marko et al., 1991, 1995; Fodor, 1995; Kováč and Hók, 1996; Fodor et al., 1999).

\section{THIRD $\left(D_{3}\right)$ DEFORMATION STAGE, NNW-SSE COMPRESSION} (OTTNANGIAN-EARLY BADENIAN)

This third deformation phase is represented by faults generated by a compressional regime with the NNW-SSE oriented, nearly horizontal $\sigma_{1}$. It resulted in formation of conjugate strike-slip faults, including NNE-SSW oriented sinistral strike-slip faults that predominate over NW-SE striking dextral strike-slip faults (Fig. 6). There are also multiple SW-NE to WSW-ENE trending reverse faults, which were measured at all locations (except for Skalica - locality 5). The palaeostress field of this orientation was found typical of the Ottnangian-Early Badenian interval (Marko et al., 1991, 1995; Fodor, 1995; Kováč and Hók, 1996; Fodor et al., 1999).

\section{FOURTH $\left(D_{4}\right)$ DEFORMATION STAGE, NNE-SSW COMPRESSION AND WNW-ESE EXTENSION (MIDDLE-LATE BADENIAN)}

Compression continued during the fourth deformation phase that resulted from shifting of the principal compression axis toward the NNE-SSW to NE-SW orientation. The NW-SE trending reverse faults were associated with this phase. In a declining compressional tectonic regime, conjugate strike-slip faults were formed, whereas the number of reverse faults decreased and the number of normal faults increased (Fig. 7). The sinistral strike-slip faults oriented ENE-WSW prevail over the NNW-SSE dextral strike-slip faults. At the same time, normal, predominantly west-dipping faults, detected especially in the Butkov quarry (locality 1), Tunežice quarry (locality 2) and Manín locations (locality 4), were related to WNW-ESE oriented extension as the overall tectonic regime changed gradually from transpressional to transtensional by rotation of the principal compressive stress axis into a subvertical position in a stable NNE-SSW orientation. The fault system generated under a compressional to transtensional regime with the resolved palaeostress field characterized by the NNE-SSW oriented maximum horizontal stress axis SHmax is dated back to the Middle-Late Badenian (Hók et al., 1995; Marko et al., 1995; Kováč and Hók, 1996).

\section{FIFTH $\left(D_{5}\right)$ DEFORMATION STAGE, NE-SW COMPRESSION} AND NW-SE EXTENSION (SARMATIAN-PANNONIAN)

The fifth deformation phase is characterized by sinistral transtension, when the main horizontal compression axis SHmax maintained its NE-SW orientation (Fig. 8). Abundant normal faults formed at that time outnumbered the conjugate strike-slip faults, which were identified particularly in the Butkov (locality 1), Tunežice (locality 2) and Mojtín quarries (locality 3 ). The locality Skalica (locality 5) is an exception, because dextral 
$\mathrm{N}-\mathrm{S}$ faults dominate over the sinistral $\mathrm{W}-\mathrm{E}$ trending strike-slip faults. On the other hand, the numerous NE-SW oriented and moderately NW-dipping normal faults indicate a primary role of NW-SE oriented extension (Fig. 8). This phase is affiliated with the Sarmatian-Pannonian interval (Marko et al., 1991, 1995; Fodor, 1995; Hók et al., 1995; Kováč and Hók, 1996; Fodor et al., 1999).

\section{SIXTH $\left(D_{6}\right)$ DEFORMATION STAGE, NW-SE EXTENSION (PLIOCENE-QUATERNARY)}

The sixth and last deformation phase is characterized by a number of conjugate normal faults as the result of a purely extensional tectonic regime with the NW-SE oriented least principal stress axis $\sigma_{3}$. Frequently, the NE-SW-trending normal faults (Figs. 3A and 9) reactivated the pre-existing weakness zones - either the bedding planes, or older reverse faults. The existence of so many normal faults is likely caused by the relaxation of compressive tectonic stresses in the area. The timing of this youngest tectonic phase is constrained by the results of structural investigations in nearby areas, where Vojtko et al. (2008, 2010), Pešková et al. (2009) and Králiková et al. (2010) determined similar homogeneous fault groups and dated them back to the Pliocene and Quaternary. Comparable results come from the Danube and Vienna basins, where prevailing extensional stresses were considered to have occurred during the Late Miocene-Pliocene (Marko et al., 1995; Fodor, 1995; Fodor et al., 1999).

\section{DISCUSSION}

The tectonic structures measured in the study area revealed changes in the palaeostress field during the Eocene-Pliocene. These changes are illustrated in Figure 10 by stress diagrams showing the orientation of the horizontal components SHmax and Shmin of the stress field rotating clockwise (CW) about a vertical axis through time. In the text, the orientation of the stress field is approximated by the orientation of the principal horizontal stress SHmax, except for the sixth $\left(D_{6}\right)$ deformation stage when this axis was vertical.

Gradual reorientation of the stress field and the change of tectonic regime from orthogonal shortening during the formation of accretionary wedge, through dextral transpression in the Late Eocene and Early Miocene, and sinistral transtension in the Mid Miocene to extension in the Late Miocene to Pliocene, resulted in the development of variable, often reactivated fault structures. However, any reconstruction of palaeostress states is complicated by the Miocene block rotation of the whole Western Carpathians (e.g., Fodor, 1995; Marko et al., 1995; Márton et al., 2016). Consequently, changes of palaeostress orientation in the area were likely caused by a combination of the clockwise rotation of the stress field and the counterclockwise $(\mathrm{CCW})$ rotation of the ALCAPA microplate.

The earliest $\left(D_{1}\right)$ deformation phase (pre-Late Eocene) is characterized by the $\mathrm{W}-\mathrm{E}$ trending main horizontal compression axis SHmax. In this period, the Pieniny Klippen Belt was part of a convergent zone between the rigid blocks of the Central Western Carpathians and Northern European Platform. It was the time of amalgamation of the PKB Oravic units with the outer edge of the CWC and the foundation of the Outer Carpathian accretionary wedge, in which the PKB represented its internal fold-and-thrust belt with several nappe units later affected by large-scale folding (Plašienka, 2012; Plašienka and Soták, 2015). This first $\left(D_{1}\right)$ post-folding compressive phase was recorded by brittle fault structures that developed in the dominating dextral transpressional regime. Deformation structures of this stage are not observed in the Bartonian-Oligocene deposits of the Central Carpathian Paleogene Basin, therefore the first palaeostress state recorded must have occurred earlier, most probably during the late Middle Eocene. Therefore, considering a Miocene block rotation of the Western Carpathian of c. $50-60^{\circ}$ (Márton et al., 2016), the original orientation of the main compressive palaeostress axis should have been in the NNW-SSE direction (Fig. 10).

During the second $\left(D_{2}\right)$ deformation phase, the axis of the main compressive stress rotated from the W-E to the NW-SE direction. The phase is dated from the Late Oligocene (Egerian) until the Early Miocene (Eggenburgian). At this time, collision of the Western Carpathians and the Northern European Platform culminated and sedimentation in the fore-arc and piggy-back basins finished (Kováč, 2000). The presently NW-SE oriented compression, originally operating in an approximately $\mathrm{N}-\mathrm{S}$ direction (Fig. 10), resulted in folding of the Magura group of nappes and development of the dextral transpressive zone along the PKB that acquired a positive flower structural geometry (Ratschbacher et al., 1993; Plašienka et al., 1998; Bučová et al., 2010; Mello et al., 2011).

During the Ottnangian-Early Badenian, the entire Western Carpathian domain rotated as a unity about $50-60^{\circ}$ anti-clockwise (e.g., Kováč and Túnyi, 1995; Márton et al., 2016). At the same time, older deformation structures should also have rotated. The observed pre-Middle Miocene reorientation of the palaeostress field is therefore a result of the rigid block rotation under a stable palaeostress field with the approximately north-south (NNW-SSE to NNE-SSW, see Fig. 10) orientation of the main compressive axis (Marko et al., 1991, 1995, 2005; Ratschbacher et al., 1993; Kováč et al., 1994; Fodor et al., 1999). Accordingly, the structural complexity of the third $\left(D_{3}\right)$ deformation stage is related to the rotation of pre-existing structures with respect to a more-or-less stable palaeostress field. However, the complex situation with the CCW block rotation and CW palaeostress field rotation during this stage would need further detailed investigations in areas where deposits of late Early and early Middle Miocene age are preserved (cf. Márton and Fodor, 1995).

Simultaneously with the block rotation, the compression axis had generally a $\mathrm{N}-\mathrm{S}$ direction. Gradually, a sinistral shear zone of the SW-NE direction was created, which in the Middle Miocene accommodated translation of the Western Carpathians in a NE direction and resulted in a shift from transpression to transtension (Marko et al., 1991, 1995; Kováč et al., 1994, 2016; Fodor et al., 1999) during the next fourth $\left(D_{4}\right)$ deformation stage. The rotation of the paleo-stress axis from a $\mathrm{N}-\mathrm{S}$ direction to a NNE-SSW or NE-SW orientation was caused by the ALCAPA extrusion and CCW rotation resulting in block translation in a NE direction resulting in some differences in the stress regimes along the Klippen Zone and the adjacent areas (Marko et al., 1995; Kováč and Hók, 1996).

Following the block rotation, the main horizontal compressive stress axis SHmax was further shifted to the NE-SW up to the ENE-WSW direction during the fifth $\left(D_{5}\right)$ deformation, Sarmatian to Pannonian stages (Fig. 10). This change indicates additional clockwise rotation of the palaeostress field about a horizontal axis, which was likely generated by the eastward shift of an active subduction process along the outer margin of the Carpathian arc (Kováč et al., 1993, 2016; Kováč, 2000). The along-strike strike-slip faults resulting from the eastward located subduction zone reflect a progressive elongation of the Western Carpathians (Kováč et al., 1993; Kováč, 2000). The sinistral transtensional tectonic regime and formation of small pull-apart 


\begin{tabular}{|c|c|c|c|} 
Sixth stage \\
NNW-SSE extension \\
extensional regime
\end{tabular}

Fig. 10. Stress symbols in large circles and main characteristics of individual palaeostress stages with stress arrows averaging the bulk data

Black arrows - main horizontal compression axis SHmax; empty arrows - horizontal extension axis Shmin; grey circle - the intermediate stress axis. The dimensions of arrows indicate their relative magnitudes. Small circles show orientation of the main populations of fault-slip structures dominating the respective stages [green - strike-slips, red - reverse fault (indicating the direction of displacement), blue - normal faults (indicating the direction of displacement)]. Stress and strain circles for the first and second $\left(D_{1}-D_{2}\right)$ deformation stages are shown also in the pre-rotation situation, rotated back (CCW) about a vertical axis at $60^{\circ}$. The third stage is thought to have occurred during the Early/Middle Miocene block rotation (CCW) of the entire Western Carpathians, thus the circle is rotated back by $30^{\circ}$ only 
basins along the Pieniny Klippen Belt, like the llava and Orava basins, are indicative of this phase. However, the main tectonic structures, formed during rotation of the stress field and stretching of the Carpathian domain, were the NE- SWto ENE-WSW trending normal faults.

The latest $\left(D_{6}\right)$ deformation stage during the Miocene to Pliocene and Quaternary period is characterized by the onset of a general extensional tectonic regime, dominated by an extensional component of the stress field oriented in a NW-SE to NNW-SSE direction. The existence of a large number of normal faults is likely caused by the relaxation of compressive stresses in the area.

\section{CONCLUSIONS}

The area studied was deformed via a multistage ductile-brittle tectonic evolution. The history of palaeostress states, from the Middle Eocene to the Pliocene and Quaternary, was controlled by the interaction between the stable Northern European Platform and the ALCAPA microplate. The CCW rotation of the Western Carpathian part of the ALCAPA block during the Early Miocene by some $50-60^{\circ}$ about a more-or-less stable orientation of the $\sigma_{1}$ axis played a dominant role in the reorientation of palaeostress fields (Kováč et al., 1994; Kováč and Túnyi, 1995; Marko et al., 1995). During the Sarmatian-Pannonian, active clockwise rotation of the main compressional stress from $\mathrm{N}-\mathrm{S}$ to NE-SW and inversion of tectonic regimes were a result of the NE-ward translation of the entire ALCAPA block (Marko et al., 1995; Kováč and Hók, 1996).

The reconstruction of palaeostress fields performed in this work was carried out using fault-slip data from five localities in the Manín Unit. Palaeostress analysis revealed the existence of six different stress states developed during four tectonic regimes during the Eocene-Pliocene times.

A transpressional tectonic regime in the first $D_{1}$ and second $\mathrm{D}_{2}$ deformation stages is characterized by a combination of strike-slip movement with oblique compression.

The first $D_{1}$ deformation stage (pre-Late Eocene) was accompanied by formation of NE-SW trending dextral and NW-SE trending sinistral strike-slip faults, and by NE-SW trending oblique-slip reverse faults. The nearly horizontal principal compressive stress axis $\sigma_{1}$, which is oriented in an W-E direction presently, operated in a NNW-ESE direction originally (pre-rotation state in Fig. 10). Generally, the faults were activated under a dextral transpressional tectonic regime.

The second $\mathrm{D}_{2}$ deformation stage (Egerian-Eggenburgian) is characterized by the NW-SE to WNW-ESE oriented SHmax (NNE-SSW in the pre-rotation state; Fig. 10) and resulted in a transpressional to compressional tectonic regime, with predominantly NNE-SSW trending right-lateral, NW-SE left-lateral faults and rare NE-SW trending reverse faults (all in the present coordinates).

A compressional tectonic regime during the $D_{3}$ and $D_{4}$ deformation stages was associated with subvertical orientation of the minimum stress axis.

The third $D_{3}$ deformation stage (Ottnangian-Early Badenian) reflected the change of tectonic regime from transpression-dominated to compressional with the presently NNW-SSE oriented maximum horizontal stress axis SHmax. This stage operated concurrently with the CCW block rotations, thus the stress field is interpreted to have been oriented relatively stably with the roughly $\mathrm{N}-\mathrm{S}$ direction of SHmax.

The post-rotation fourth $\mathrm{D}_{4}$ deformation stage (Middle-Late Badenian) included prolonged compression with the $\mathrm{N}-\mathrm{S}$ (NNE-SSW) oriented SHmax axis. Generally, normal faults and sinistral strike-slip faults were formed as a result of the next transtensional tectonic regime combining strike-slip movement with oblique extension.

The fifth $\mathrm{D}_{5}$ deformation stage (Sarmatian-Pannonian) reflects the next change of tectonic regime that occurred during WSW-ENE compression, where dextral strike-slip faults and normal faults dominated. Normal faults resulted from NW-SE oriented extension along the Shmin axis. Orientation of the maximum stress axis SHmax was subvertical.

The sixth $D_{6}$ deformation stage (Pliocene to Quaternary) is characterized by a number of conjugate normal faults as the result of an extensional tectonic regime with the NW-SE oriented Shmin axis.

The reconstructed history of palaeostress states and their rotations, partitioned into six $\left(D_{1}-D_{5}\right)$ principal deformation stages in the Manín Unit, largely corresponds to the palaeostress reconstructions performed in neighbouring areas as well as in the entire Western Carpathian segment of the ALCAPA microplate. Our study supplements the earlier results and puts new constraints on the tectonic history of this domain from the Middle Eocene onwards.

Acknowledgements. This paper is produced from a doctoral research programme conducted at the Comenius University in Bratislava, Slovakia. We would like thank the editor Prof. P. Aleksandrowski and reviewers Prof. S. Mazur, Prof. Z. Cymerman and an anonymous reviewer for the detailed reviews and constructive comments that considerably improved the quality of this manuscript. This work was supported by the Slovak Research and Development Agency under the contracts APVV-0212-12, APVV-0315-12, APVV-15-0050, VEGA 1/0650/15, KEGA 005UMB-4/2016.

\section{REFERENCES}

Andrusov, D., 1938. Geologický výzkum vnitřního bradlového pásma v Západních Karpatech III. Tektonika (in Czech). Rozpravy státního geologického ústavu ČSR, 9, Praha.

Andrusov, D., 1968. Grundriss der Tektonik der Nördlichen Karpaten. Verlag der Slowakischen Akademie der Wissensshaften, Bratislava.

Angelier, J., 1989. From orientation to magnitudes in paleostress determinations using fault slip data. Journal of Structural Geology, 11: $37-50$.
Angelier, J., 1994. Fault slip analysis and palaeostress reconstruction. In: Continental Deformation (ed. P.L. Hancock): 53-100. Pergamon Press, University of Bristol, London.

Angelier, J., Mechler, P., 1977. Sur une method graphique de recherché des contraintes principals egalement utilizable en tectonique et en seismologie: La méthode des dièdres droits. Bulletin de la Société géologique de France, 19: 1309-1318.

Began, A., 1961. Správa za rok 1960 o podrobnom geologickom výskume bradlového pásma $v$ okolí Púchova a Považskej Bystrice (in Slovak). MS - archív GÚDŠ, Bratislava. 
Began, A., Salaj, J., Hanáček, J., Rakús, M., Nemčok, J., Maršalko, R., Gabčo, R., Kalaš, L., Kullman, E., 1963. Záverečná správa za úlohu „Základný geologický výskum a mapovanie v merítku 1:25 000 a 1:50 000, spojený s edíciou máp v merítku 1:50 000, list Považská Bystrica - Manuskript (in Slovak). Archív GÚDŠ, Bratislava.

Borza, K., $1980 . \quad$ Litologicko-mikrofaciálna charakteristika vrchnojurských a spodnokriedových sedimentov belianske série (Strážovské vrchy) (in Slovak). Geologické Práce, Správy, 74: 33-56.

Borza, K., Michalík, J., Vašíček, Z., 1987. Lithological, biofacia and geochemical characterisation of the Lower Cretaceous pelagic carbonate sequences of Mt. Butkov (in Slovak with English summary). Geologický Zborník - Geologica Carpathica, 38 323-348.

Bott, M.H.P., 1959. The mechanics of oblique slip faulting. Geological Magazine, 96: 109-117.

Bučová, J., 2013. Geological structure and structural evolution of the western part of the Pieniny Klippen Belt (in Slovak with English summary). Unpubl. Ph.D. thesis, Comenius University, Bratislava.

Bučová, J., Plašienka, D., Mikuš, V., 2010. Geology and tectonics of the Vršatec klippen area (Pieniny Klippen Belt, western Slovakia). Scientific Annals, School of Geology, Aristotle University of Thessaloniki, Special Volume, 100: 197-207.

Delvaux, D.F., 1993. The TENSOR program for paleostress reconstruction: examples from the east African and the Baikal rift zones. Terra Nova, 5, suppl no. 1, Proceedings of EUG VII Strasbourg.

Delvaux, D., 2006. WINTENSOR, VERSIO 1.3.75, Royal Museum for Central Africa, Tervuren, Belgium Dept. Geology - Mineralogy.

Delvaux, D., Sperner, B., 2003. Stress tensor inversion from fault kinematic indicators and focal mechanism data: the TENSOR program. Geological Society Special Publications, 212: 75-100.

Delvaux, D., Moeys, R., Stapel, G., Melnikov, A., Ermikov, V., 1995. Paleostress reconstruction and geodynamics of the Baikal region, Central Asia. Part I. Pre-rift evolution: Paleozoic and Mesozoic. Tectonophysics, 252: 61-101.

Delvaux, D., Moeys, R., Stapel, G., Petit, C., Levi, K., Miroshnichenko, A., Ruzhich, V., Sankov, V., 1997. Paleostress reconstructions and geodynamics of the Baikal region, Central Asia. Part II: Cenozoic rifting. Tectonophysics, 282: 1-38.

Dupin, J.M., Sassi, W., Angelier, J., 1993. Homogeneous stress hypothesis and actual fault slip: a distinct element analysis. Journal of Structural Geology, 15: 1033-1043.

Fodor, L., 1995. From transpression to transtension Oligocene-Miocene structural evolution of the Vienna basin and the East Alpine-Western Carpathian junction. Tectonophysics, 242: 151-182.

Fodor, L., Csontos, L., Bada, G., Györfi, I., Benkovics, L., 1999 Tertiary tectonic evolution of the Pannonian Basin system and neighbouring orogens: a new synthesis of palaeostress data Geological Society Special Publications, 156: 295-334.

Froitzheim, N., Plašienka, D., Schuster, R., 2008. Alpine tectonics of the Alps and Western Carpathians. In: The Geology of Central Europe, 2: Mesozoic and Cenozoic (ed. T. McCann) 1141-1232. Geological Society Publishing House, London.

Hók, J., Šimon, L., Kováč, P., Elečko, M., Vass, D., Halmo, J. Verbich, F., 1995. Tectonics of the Hornonitrianska kotlina Depression in the Neogene. Geologica Carpathica, 46: 191-196.

Kováč, M., 2000. Geodynamický, paleogeografický a štruktúrny vývoj karpatskopanónskeho regiónu v miocéne: nový pohl'ad na neogénne panvy Slovenska (in Slovak). Veda, Bratislava.

Kováč, M., Túnyi, I., 1995. Interpretation of the paleomagnetic data from western part of the Central Western Carpathians. Mineralia Slovaca, 27: 213-220

Kováč, M., Michalík, J., Plašienka, D., Mat'o, L'., 1993. Alpínsky vývoj Západných Karpát (in Slovak). Masarykova univerzita, Brno.
Kováč, M., Král', J., Márton, E., Plašienka, D., Uher, P., 1994. Alpine uplift history of the Central Western Carpathians: geochronological, paleomagnetic, sedimentary and structural data. Geologica Carpathica, 45: 83-96.

Kováč, M., Plašienka, D., Soták, J., Vojtko, R., Oszczypko, N., Less, Gy., Ćosović, V., Fugenschuh, B., Králiková, S., 2016. Paleogene palaeogeography and basin evolution of the Western Carpathians, Northern Pannonian domain and adjoining areas. Global and Planetary Change, 140: 9-27.

Kováč, P., Hók, J., 1996. Tertiary development of the western part of Klippen Belt. Slovak Geological Magazine, 2: 137-149.

Králiková, S., Hók, J., Vojtko, R., 2010. Stress change inferred from the morphostructures and faulting of the Pliocene sediments in the Hronská pahorkatina highlands (Western Carpathians) (in Slovak with English summary). Acta Geologica Slovaca, 2: 17-22.

Maerten, L., 2000. Variation in slip on intersecting normal faults: Implications for paleostress inversion. Journal of Geophysical Research, 105 (B11): 25553-25565.

Mahel', M., 1967. Regionální geologie ČSSR II. Západní Karpaty. Svazek 1 (in Czech). ÚúG ČSAV, Praha.

Mahel', M., 1978. Manín tectonic unit: relation of the Klippen Belt and Central West Carpathians. Geologický Zborník Geologica Carpathica, 29: 197-214

Mahel', M., 1980. The Periklippen zone: nearer characterization and significance (in Slovak with English summary). Mineralia Slovaca, 12: 193-207.

Mahel', M., 1985. Geologická stavba Strážovských vrchov. GÚDŠ + mapa 1:50 000 (in Slovak), Bratislava.

Mahel', M., 1986. Geologická stavba československých Karpát. Paleoalpínske jednotky 1 (in Slovak). Vydavatel'stvo Veda, Bratislava.

Marko, F., 2000. Štruktúrna geológia II (in Slovak). Univerzita Komenského, 124.

Marko, F., Fodor, L., Kováč, M., 1991. Miocene strike-slip faulting and block rotation in Brezovské Karpaty Mts. (Western Carpathians). Mineralia Slovaca, 23: 189-200.

Marko, F., Plašienka, D., Fodor, L., 1995. Meso-Cenozoic tectonic stress fields within the Alpine-Carpathian transition zone: a review. Geologica Carpathica, 46: 19-27.

Marko, F., Vojtko, R., Plašienka, D., Sliva, L'., Jablonský, J., Reichwalder, P., Starek, D., 2005. A contribution to the tectonics of Periklippen zone near Zázrivá (Western Carpathians). Slovak Geological Magazine, 11: 37-43.

Márton, E., Fodor, L., 1995. Combination of paleomagnetic and stress data - a case study from North Hungary. Tectonophysics, 242: 99-114.

Márton, E., Grabowski, J., Tokarski, A., Túnyi, I., 2016 Paleomagnetic results from the fold and thrust belt of the Western Carpathians: an overview. Geological Society Special Publications, 425: 7-36.

Marschalko, R., Kysela, J., 1979. Geology and tectonics of the Pieniny Klippen Belt and the Manín unit between Žilina and Považská Bystrica (in Slovak with English summary). In: Tectonic profiles through the Western Carpathians (ed. M. Mahel'): 41-58. Geol. Úst. D. Štúra, Bratislava.

Mello, J., ed., Potfaj, M., Tet’ák, F., Havrila, M., Rakús, M., Buček I., Filo, I., Nagy, A., Salaj, J., Maglay, J., Pristaš, J., Fordinál, K., 2005. Geologická mapa Stredného Považia (in Slovak). MŽP SR, ŠGÚDŠ, Bratislava.

Mello, J., ed., Boorová, D., Buček, S., Filo, I., Fordinál, K., Havrila, M., Iglárová, L', Kubeš, P., Liščák, P., Maglay, J., Marcin, D., Nagy, A., Potfaj, M., Rakús, M., Rapant, S., Remšík, A., Salaj, J., Siráňová, Z., Teták, F., Zuberec, J., Zlinská, A., Žecová, K., 2011. Vysvetlivky ku geologickej mape Stredného Považia (1: 50 000) (in Slovak). ŠGÚDŠ, Bratislava.

Michalík, J., 1992. Comments on the Mesozoic palinspastic interpretations of the Western Carpathians. Acta Geologica Hungarica, 35: 39-47. 
Michalík, J., 1994. Notes on the paleogeography and paleotectonics of the Western Carpathian area during the Mesozoic. Mitteilungen der Österreichischen Geologischen Gesellschaft, 86: 101-110.

Michalík, J., Vašíček, Z., 1984. To the early Mid Cretaceous West Carpathian development: the age and environmental position of the „Skalica Breccia”. Geologický Zborník - Geologica Carpathica, 35: 559-581.

Michalík, J., Lintnerová, O., Reháková, D., Boorová, D., Šimo, V., 2012. Early Cretaceous sedimentary evolution of a pelagic basin margin (the Manín Unit, central Western Carpathians, Slovakia). Cretaceous Research, 38: 68-79.

Michalík, J., Vašíček, Z., Boorová, D., Golej, M., Halásová, E., Hort, P., Ledvák, P., Lintnerová, O., Měchová, L., Šimo, V., Šimonová, V., Reháková, D., Schlögl, J., Skupien, P., Smrečková, M., Soták, J., Zahradníková, B., 2013. The Butkov Hill - a stone archive of Slovakian mountains and the Mesozoic sea life history (in Slovak and English). Veda, Bratislava.

Nemčok, J., 1980. Analýza štruktúrnych foriem bradlového pásma na východnom Slovensku (in Slovak). Manuskript - archív GUDŠ, Bratislava.

Nemčok, M., Nemčok, J., 1994. Late Cretaceous deformation of the Pieniny Klippen Belt, West Carpathians. Tectonophysics, 239: 81-109.

Nieto-Samaniego, A.F., Alaniz-Alvarez, S.A., 1996. Origin and tectonic interpretation of multiple fault patterns. Tectonophysics, 270: 197-206.

Pešková, I., Vojtko, R., Starek, D., Sliva, L., 2009. Late Eocene to Quaternary deformation and stress field evolution of the Orava region (Western Carpathians). Acta Geologica Polonica, 59: 73-91.

Petit, J.P., 1987. Criteria for the sense of movement on fault surfaces in brittle rocks. Journal of Structural Geology, 9: 597-608.

Plašienka, D., 1995. Mesozoic evolution of Tatric units in the Malé Karpaty and Považský Inovec Mts.: implications for the position of the Klape and related units in western Slovakia. Geologica Carpathica, 46: 101-112.

Plašienka, D., 2012. Jurassic syn-rift and Cretaceous syn-orogenic, coarse-grained deposits related to opening and closure of the Vahic (South Penninic) Ocean in the Western Carpathians - an overview. Geological Quarterly, 56 (4): 601-628.

Plašienka, D., Soták, J., 2015. Evolution of Late Cretaceous-Palaeogene synorogenic basins in the Pieniny Klippen Belt and adjacent zones (Western Carpathians, Slovakia): tectonic controls over a growing orogenic wedge. Annales Societatis Geologorum Poloniae, 85: 43-76.

Plašienka, D., Soták, J., Prokešová, R., 1998. Structural profiles across the Šmbron-Kamenica Periklippen Zone of the Central Carpathian Paleogene Basin in NE Slovakia. Mineralia Slovaca, 29: 173-184.

Plašienka, D., Michalík, J., Soták, J., Aubrecht, R., 2017. Discussion of "Olistostromes of the Pieniny Klippen Belt, Northern Carpathians”. Geological Magazine, 154: 187-192.

Pollard, D.D., Saltzer, S.D., Rubin, A.M. 1993. Stress inversion method: are they based on faulty assumptions? Journal Structural Geology, 15: 1045-1054.

Prokešová, R., Plašienka, D., Milovský, R., 2012. Structural pattern and emplacement mechanisms of the Krížna cover nappe (Western Carpathians, Slovakia). Geologica Carpathica, 63: 13-32.
Rakús, M., 1977. Doplnky k litostratigrafii a paleogeografii jury a kriedy manínskej série na strednom Považí (in Slovak). Geologické Práce, Správy, 69: 21-38.

Rakús, M., Hók, J., 2005. The Manín and Klape units: Lithostratigraphy, tectonic classification, paleogeographic position and relationship to Váhicum (in Slovak with English summary). Mineralia Slovaca, 37: 9-26.

Rakús, M., Potfaj, M., Vozárová, A., 1998. Basic paleogeographic and paleotectonic units of the Western Carpathians. In: Geodynamic Development of the Western Carpathians (ed. M. Rakús): 15-26. Geological Survey of Slovak Republic, Dionýz Štúr Publishers, Bratislava.

Ratschbacher, L., Frisch, W., Linzer, H.G., Sperner, B., Meschede, M., Decker, K., Nemčok, M., Nemčok, J., Grygar, R., 1993. The Pieniny Klippen Belt in the Western Carpathians of northeastern Slovakia: structural evidence for transpression. Tectonophysics, 226: 471-483.

Reháková, D., Michalík, J., 1994. Abundance and distribution of Upper Jurassic and Lower Cretaceous microplankton in Western Carpathians. Geobios, 27 : 135-156.

Roberts, G.P., Ganas, A., 2000. Fault-slip directions in central and southern Greece measured from striated and corrugated fault planes: comparison with focal mechanism and geodetic data. Journal of Geophysical Research, 105 (B10): 23443-23462.

Salaj, J., 1990. Geological structure of the Klippen and Periklippen zones in the Middle Váh river valley and lithological classification of Cretaceous sediments from the newly defined sequences (in Slovak with English summary). Mineralia Slovaca, 22: 155-174.

Salaj, J., Samuel, O., 1966. Foraminiferen der Westkarpaten-Kreide. Vyd. Geol. Úst. D. Štúra, Bratislava.

Soták, J., Pereszlényi, M., Marschalko, R., Milička, J., Starek, D., 2001. Sedimentology and hydrocarbon habitat of the submarine-fan deposits of the central Carpathian Paleogene Basin (NE Slovakia). Marine and Petroleum Geology, 18: 87-114.

Sperner, B. Müller, B., Heidbach, O., Delvaux, D., Reinecker, J., Fuchs, K., 2003. Tectonic stress of the Earth's crust: advances in the World Stress Map Project. Geological Society Special Publications, 212: 101-128.

Šimonová, V., Plašienka, D., 2011. Fault kinematics and paleostress analysis in the Butkov quarry (Manín Unit, Western Carpathians) (in Slovak with English summary). Acta Geologica Slovaca, 3: 21-31.

Twiss, R.J., Unruh, J.R., 1998. Analysis of fault slip inversions: do they constrain stress or strain rate? Journal of Geophysical Research, 101: 8335-8361.

Vašíček Z., Michalík J., Reháková D., 1994. Early Cretaceous stratigraphy, paleogeography and life in Western Carpathians. Beringeria, 10: 3-169.

Vojtko, R., Marko, F., 2006. Paleonapät'ová analýza, ako nástroj geodynamických rekonštrukcií. In: Nové metódy a výsledky výskumu v geológii Západných Karpát (in Slovak) (eds. M. Kováč and K. Dubíková): 77-90. GEO-GRAFIKA, Bratislava.

Vojtko, R., Hók, J., Kováč, M., Sliva, L., Joniak, P., Šujan, M., 2008. Pliocene to Quaternary stress field change in the Western Carpathians (Slovakia). Geological Quarterly, 52 (1): 19-30.

Vojtko, R., Tokárová, E., Sliva, L'., Pešková, I., 2010. Cenozoic palaeostress field reconstruction and revised tectonic history in the northern part of the Central Western Carpathians (the Spišská Magura and Tatra Mountains). Geologica Carpathica, 61: 211-225.

Wallace, R.E., 1951. Geometry of shearing stress and relation to faulting. The Journal of Geology, 59: 118-130. 